\title{
ПОЛЕВЫЕ ИССЛЕДОВАНИЯ КАМЕННОГО ВЕКА В ЗАПАДНО-КАЗАХСТАНСКОЙ ОБЛАСТИ в 2018 годУ (предварительное сообщение) ${ }^{1}$
}

\author{
(C) 2019 г. Т.Б. Мамиров, Н.М. Баиров, Е.Е. Клышев, \\ К.Б. Мамиров, С.Р. Куандык
}

В статье приводятся предварительные сведения о полевых исследованиях, проведенных сотрудниками Института археологии им. А.Х. Маргулана на стоянках каменного века в бассейне р. Деркул в 2018 г. Памятники Вавилино 1 и Деркул 1 расположены в долине р. Деркул и имеют сохранившиеся культурные слои, что делает эти памятники уникальными для изучения каменного века региона, так как памятников с сохранившимся культурным слоем в Западном Казахстане единицы. Проведенные в 2018 г. археологические раскопки показали наличие мощных культурных отложений на памятниках, богатые археологические находки в виде каменных артефактов, фрагментов керамики, костных остатков. Памятники предварительно датируются неолит-энеолитическим временем, более точный возраст будет получен по результатам радиоуглеродного анализа. Наличие большого количества костных остатков животных позволит определить их видовую принадлежность, а также решить вопросы доместикации некоторых из них в регионе. В настоящее время памятники относятся к категории аварийных, что также вызывает необходимость их скорейшего исследования.

Ключевые слова: археология, каменный век, неолит, энеолит, стратиграфия, костные остатки, культура, индустрия, керамика, каменное сырье

В полевом сезоне 2018 г. сотрудниками Института археологии им. А.Х. Маргулана были проведены археологические работы на памятниках каменного века Деркул 1, Вавилино 1 и Ешкитау (рис. 1). Если на палеолитической стоянке Ешкитау работы велись для определения границ памятника, то на первых двух памятниках были получены интересные материалы неолит-энеолитического времени.

Памятник Деркул 1, расположен на левом берегу одноименной реки в пределах 1 км от пос. Бирлик
(Кузнецово). Через памятник проходит водозащитный вал, который вскрыл северную часть памятника, южнее памятника расположены водосборники. Севернее памятника находится сопка сложенная кварцитовидным песчаником (сырье для каменных изделий), на которых встречены изделия палеолитического облика.

Стоянка Вавилино 1 расположена на правом берегу р. Деркул в 2 км к ЮВ от пос. Бастау (Вавилино). Памятник относится к категории аварийных, вдоль берега проведен искусственный вал для водотока, 


\section{ҚАЗАҚСТАН АРХЕОЛОГИЯСЫ № 1 (3) 2019}

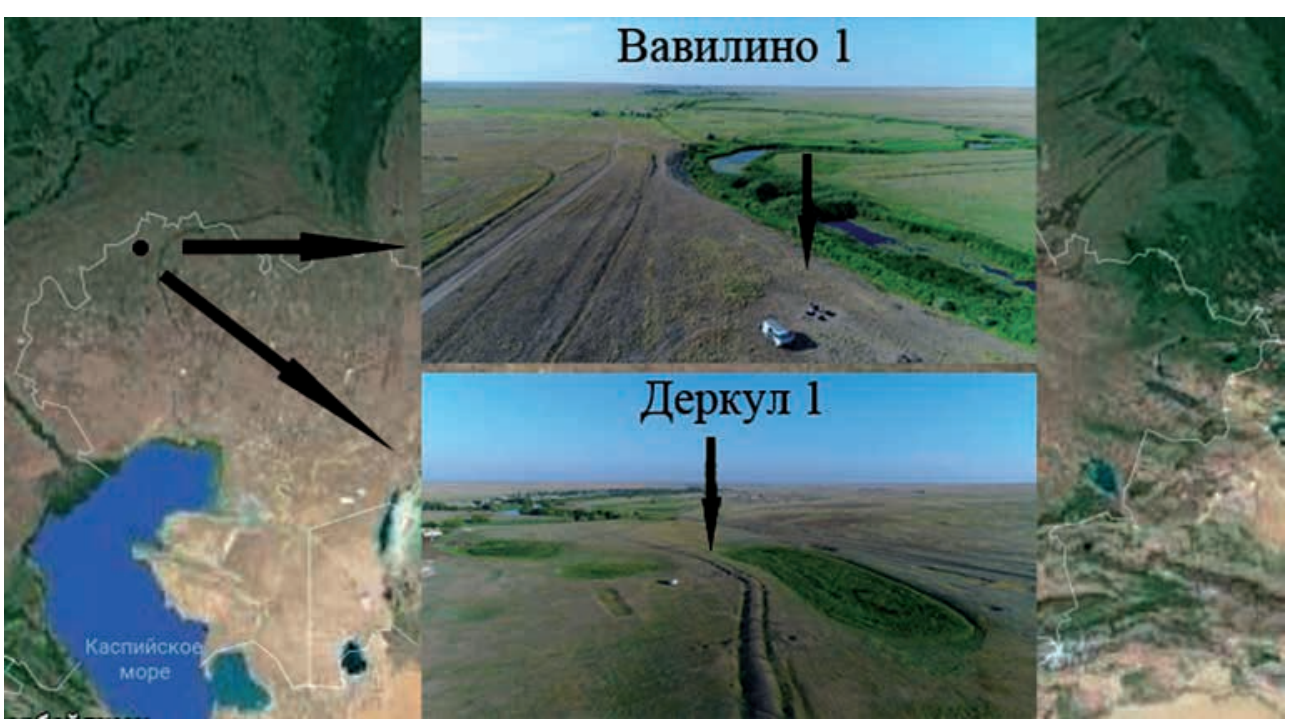

Рис. 1. Расположение памятников Вавилино 1 и Деркул 1. Фото Т.Б. Мамирова

Fig. 1. Location of the sites Vavilino 1 and Derkul 1. Photo by Mamirov T. B.

восточнее расположены огороды и водосборники, юго-западнее проведен газопровод и находятся пашни. Обрыв подмывают воды Деркула, обнажая культурные слои.

Впервые памятники в бассейне p. Деркул были обнаружены в 1986 г. Приволжской экспедицией Саратовского государственного университета под руководством Н.М. Малова [Малов, 1986]. Основной целью экспедиции было выявление памятников срубной культуры для составления Свода памятников данной культуры в Волго-Уральском междуречье. В ходе разведочных работ в бассейне реки Деркул было обнаружено более 20 памятников неолит-энеолитического времени.

На стоянке Вавилино 1 (Вавилово 2 по Н.М. Малову) 2 был собран подъемный материал на площади $25 \times 80$ кв.м, это каменные артефакты из кварцита (303 экз.), кремнистых пород (49 экз.), фрагменты керамики (26 экз.) и костные остатки. По типу изделий артефакты из кремнистых пород были отнесены автором к не- олитическому времени, а из кварцита - к энеолиту.

На стоянке Деркул 1 был собран подъемный материал с площади $40 \times 140$ м, отмечено, что по процентному соотношению большинство артефактов выполнено из кварцита и единично - из кремнистых пород, в соотношении 303 на 39. Притом кремень больше использован в пластинчатой индустрии (82\%), а кварцит в отщеповой (77\%). Также на памятнике был обнаружены фрагменты керамики (35 экз.), из которых два имеют следы орнамента. Памятник был отнесен автором к энеолитическому времени [Малов, 1986, с. 16].

В 1988 г. Волго-Уральской археологической экспедицией под руководством Н.М. Малова были проведены повторные поверхностные сборы на вышеуказанных памятниках, а также раскопки на памятнике энеолита Кузнецово 1. По характеру каменной индустрии были отнесены к эпохе неолита-энеолита [Малов, 1988]. Материалы сбора артефактов со стоянки Деркул по- 
зволили исследователю отнести его к типу самарско-прикаспийских энеолитических памятников [Малов, 1989, с. 86].

В 1991 г. исследования на памятниках были проведены Оренбургской археологической экспедицией под руководством Н.Л. Моргуновой [Моргунова, 1991].

\section{На стоянке Вавилино 1} Н.Л. Моргуновой были заложены два раскопа общей площадью 28 кв.м, в которых обнаружены 445 каменных артефактов, 14 фрагментов неорнаментированной керамики, 46 костей животных, из которых определимы кости крупного быка, лошадей и сайги. Памятник исследователем предварительно отнесен к неолитическому времени, а керамика соотнесена с ранненеолитической елшанского типа [Моргунова, 1991, с. 6-7]. Памятник предположительно определялся как самая южная точка елшанской культуры: «Если дальнейшие раскопки Вавилинской стоянки подтвердят ее связь с кругом елшанских памятников, то это будет самая южная точка распространения данной культуры» [Моргунова, 1995, с. 224].

На стоянке Деркул 1 в 1991 г. на месте большей концентрации артефактов также был заложен раскоп площадью 20 кв.м, в котором было обнаружено 17 фрагментов керамики, 480 каменных артефактов, 123 костей животных, из которых определимы кости куланов, сайги, волка, овцы, КРС, лошадей, туров. В целом памятник отнесен к энеолитическому времени [Моргунова, 1991, с. 6-7]. К сожалению, несмотря на перспективность исследований, работы на памятниках по ряду определенных обстоятельств были прекращены.

В 2016 г. сотрудником ЗападноКазахстанского областного центра археологии, истории и этнографии Д.В. Марыксиным [устное сообщение - прим. авт.] в районе стоянки Вавилино 1 были проведены разведочные работы с зачисткой кромки обрыва и небольшими сборами. Размыв водами р. Деркул культурного слоя памятника создавал угрозы уничтожению уникальных стоянок с сохранившими культурными слоями. В 2018 г. сотрудниками Института археологии им. А.Х. Маргулана были предприняты работы по исследованию аварийных (на данный момент) памятников Деркул 1, Вавилино 1 и проведены разведочные работы.

На стоянке Вавилино 1 был заложен раскоп площадью 16 кв.м западнее раскопа 2 (1991 г.) (рис. 2). Раскопочные работы велись послойно по 10 см, с просеиванием грунта через сито. На дневной поверхности был поднят один вторичный скол из кварцитовидного песчаника без обработки, размерами $21,7 \times 27,8 \times 6,9$ мм. В слое, глубиной до 50 см, выявлены более 1000 каменных артефактов, фрагментов керамики, костных остатков и дерева (табл. 1).

Таблица 1

Количество артефактов по глубинам на стоянке Вавилино 1

Table 1

Number of artifacts by depth in the settlement of Vavilino 1

\begin{tabular}{|c|c|c|c|c|c|c|c|}
\hline Артефакты & $\begin{array}{c}0 \\
\text { см }\end{array}$ & $\begin{array}{c}0-10 \\
\text { см }\end{array}$ & $\begin{array}{c}10-20 \\
\text { см }\end{array}$ & $\begin{array}{c}20-30 \\
\text { см }\end{array}$ & $\begin{array}{c}30-40 \\
\text { см }\end{array}$ & $\begin{array}{c}40-50 \\
\text { см }\end{array}$ & Итого \\
\hline Кремнистые породы & & 3 & 46 & 40 & 43 & 18 & 150 \\
\hline $\begin{array}{c}\text { Кварцитовидный } \\
\text { песчаник }\end{array}$ & 1 & 115 & 262 & 344 & 124 & 34 & 880 \\
\hline $\begin{array}{c}\text { Фрагменты } \\
\text { керамики }\end{array}$ & 3 & 1 & 6 & 5 & 3 & 18 \\
\hline
\end{tabular}




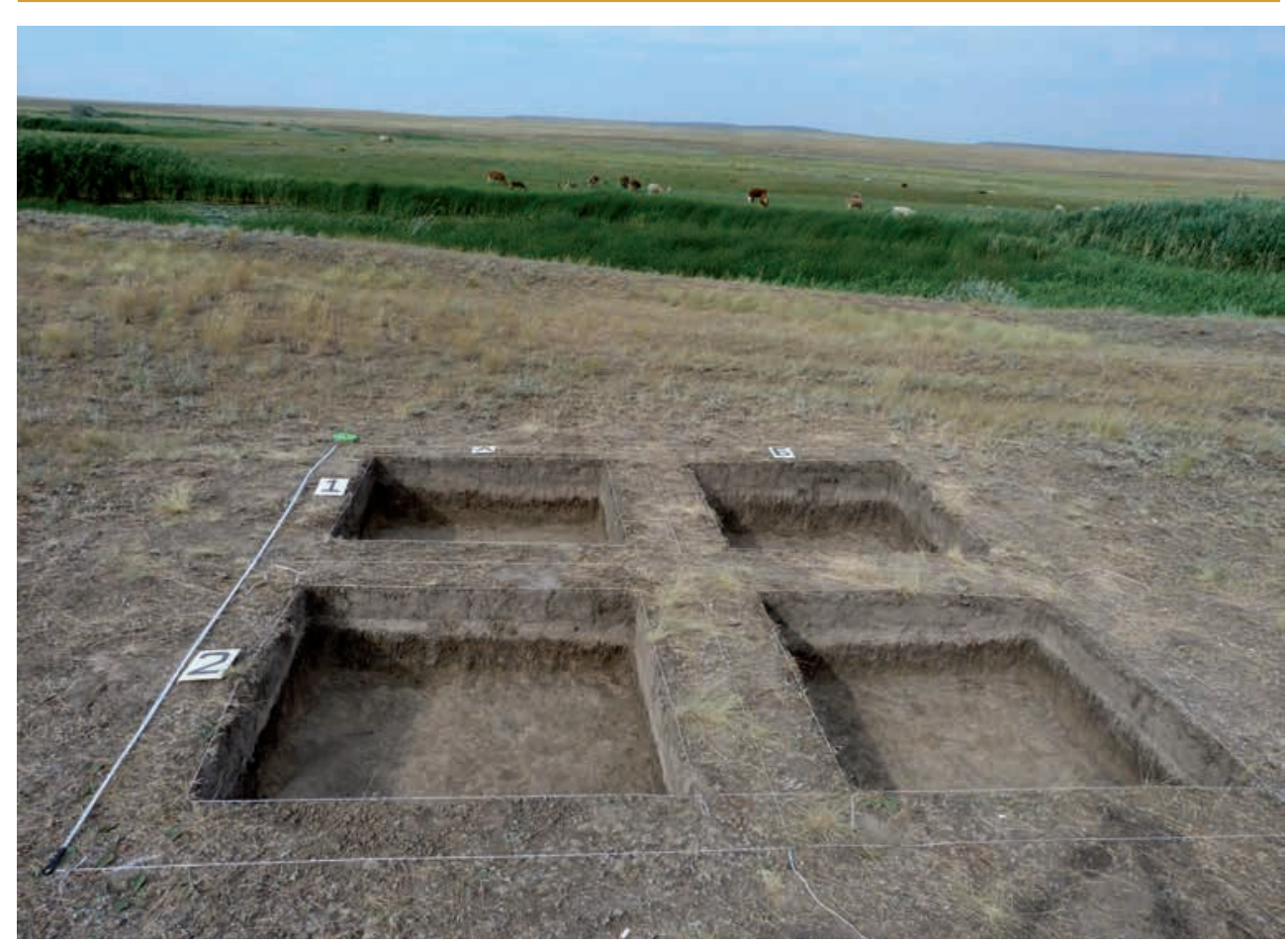

Рис. 2. Стоянка Вавилино 1, вид с юга. Фото Т.Б. Мамирова

Fig. 2. Site Vavilino 1, view from the south. Photo by Mamirov T.B.

Как видно на приведенной таблице, основным каменным сырьем для орудий послужили кремнистые породы и кварцитовидный песчаник. Соотношение артефактов из сырьевого материала в процентном отношении распределяется следующим образом: в верхних слоях кремнистое сырье составляет всего 2,5\%, дальше по глубине его количество растет до $34,6 \%$ в нижних слоях.

На глубине 0-10 см выявлены всего три артефакта из кремнистого сырья, представленные двумя концевыми скребками и медиальным фрагментом пластины. Артефакты из кварцитовидного песчаника (115 экз.) представлены такими орудиями (12 экз.), как концевые скребки, угловой скребок, фрагменты пластин с ретушью, фрагменты сколов с ретушью.
На глубине 10-20 см орудийный набор из кремнистого сырья составляет 41,3\% из всех артефактов из этого сырья. Орудия представлены следующими категориями: скребки различных модификаций, фрагменты пластин и сколов с ретушью, проколка, 8\% изделий изготовлено из кварцитовидного песчаника. Орудия представлены концевым скребком, фрагментами пластин с ретушью, отщепами с выемчатыми и зубчатыми лезвиями, а также геометрическим микролитом (трапеция).

На глубине 20-30 см орудийный набор составляет 35\% от артефактов из кремнистого сырья, представлен концевыми скребками, перфоратором, пластиной и фрагментами пластин с ретушью, фрагментами сколов с ретушью. Орудия из кварцитовидного песчаника составляют $6,4 \%$, 
представлены концевыми скребками, скреблом, выемчатым орудием, фрагментами пластин и сколов с ретушью, геометрическим микролитом (трапецией).

На глубине 30-40 см орудийный набор составляет 23,2\% от артефактов из кремнистого сырья, представлен скребками, фрагментами пластин и сколов с ретушью. Орудий из кварцитовидного песчаника - 4\%, они представлены скребком, фрагментами пластин и сколов с ретушью. В коллекции находится один одноплощадочный односторонний призматический нуклеус для пластин (рис. 3).

На глубине 40-50 см орудийный набор составляет 18,8\% от артефактов из кремнистого сырья, представлен скребками и фрагментом пластины с ретушью. Орудий из кварцитовидного песчаника - 5,9\%, представлены скребком и фрагментом пластины с ретушью.

Фрагменты керамики плохой сохранности, на памятниках были взяты пробы на ряд анализов для определения абсолютного возраста памятника и палеоклиматических условий. Индустрия отличается по составляющей сырья, для кварцитовой характерна отщеповая индустрия, для кремневой - пластинчатая. Наличие в окрестностях выходов кварцитовидного песчаника позволила насельникам использовать его в большом количестве, а также производить на стоянке орудия, об этом свидетельствует наличие нуклевидных форм, а также множество отходов производства в виде фрагментов пластин, отще- пов, чешуеек. Результаты техникотипологического анализа согласуются с предыдущими результатами, полученными в ходе изучения материалов данной стоянки. На памятнике были отобраны серии проб для получения абсолютной даты памятника и установления палеоклиматической обстановки в районе стоянки.

На памятнике Деркул 1 был заложен раскоп площадью 16 кв.м, в виду насыщенности культурными остатками, до глубины 170 см было пройдено 8 кв.м. В результате было обнаружено большое количество каменных находок (более 4000), костных остатков животных. Концентрация находок очень большая, поэтому грунт тщательно просеивался через сито для извлечения всех артефактов (рис. 4). Сырьевая база практически однородная $(98,2 \%)$ - кварцитовидный песчаник желтовато-серого и светло-серого оттенка, выходы которого расположены на ближайшей сопке к северу от памятника, крем-

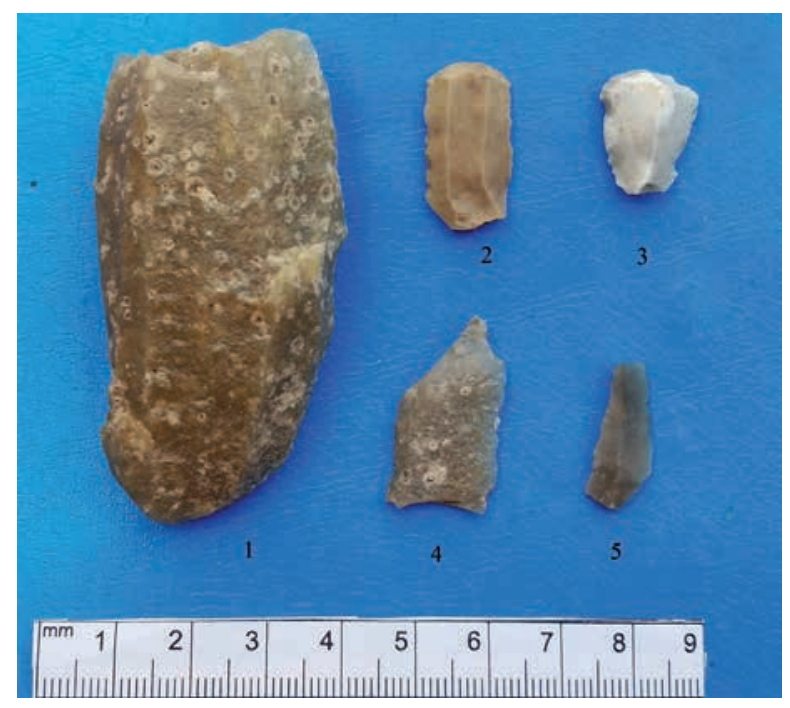

Рис. 3. Раскопки на стоянке Деркул 1. Фото Т.Б. Мамирова

Fig. 3. Excavations at the site Derkul 1. Photo by Mamirov T.B. 
нистое сырье использовано единично. Судя по большой мощности культурного слоя, на памятнике происходило быстрое накопление аллювия в энеолитическое время. Это было долговременное поселение энеолитического времени, где основным видом хозяйства были охота и скотоводство, об этом свидетельствуют наличие костей таких животных (определение П.А. Косинцева), как тура, КРС, лошади и др. [Моргунова,
1991, с. 10]. Для получения точных данных о палеоэкологической обстановке и хронологической рамке существования памятника были взяты образцы на радиоуглеродный анализ, микробиоморфный, гуминовый и др. Работы по исследованию каменных коллекций, костных остатков стоянок Вавилино 1 и Деркул 1 продолжаются, и они дополнят предварительные сведения.

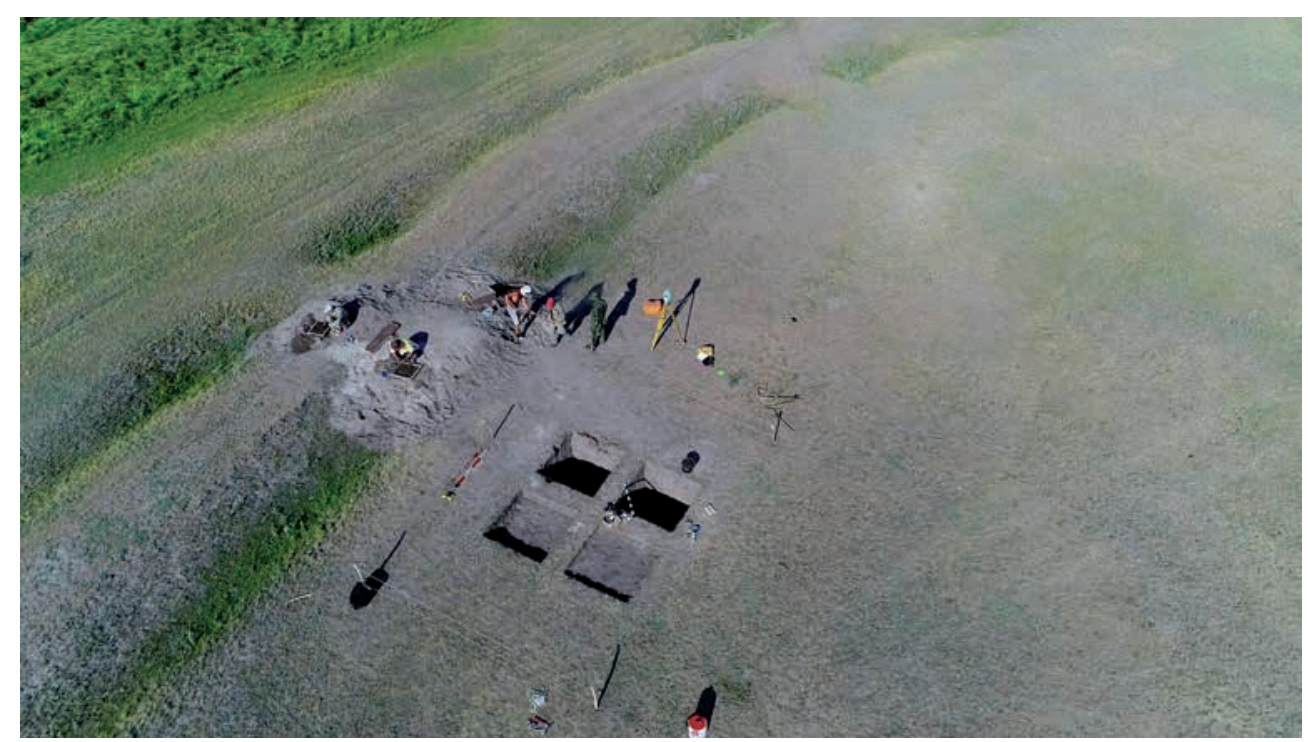

Рис. 4. Каменные изделия стоянки Вавилино 1 (глубина 30-40 см): 1 - нуклеус; 2-3 - концевые скребки; 4-5 - фрагменты пластин с ретушью. Фото Т.Б. Мамирова

Fig. 4. Stone products of the Vavilino 1 site $(30-40 \mathrm{~cm}$ depth): 1 - nucleus;

2-3-scrapers; 4-5 - fragments of blade with retouching. Photo by Mamirov T.B.

Примечания:

1 - Работа выполнена при финансовой поддержке Комитета науки Министерства образования и науки Республики Казахстан (ИРН проекта АР05134087).

2 - Следует отметить, что нами принято наименование памятника Вавилино 1 (по Н.Л. Моргуновой), так как первое наименование Вавилово 2 не соответствует административному наименованию близлежащего населенного пункта.

\section{ЛИТЕРАТУРА}

1. Малов Н.М. Отчет об археологических разведках произведенных в Каменском районе Уральской области в 1986 году // Архив ИН КН МОН РК, ф. 11, оп. 2, д. 3046

2. Малов Н.М. Разведки на Деркуле // Археологические открытия 1986 года. М.: Наука, 1988. 486 с. 
3. Малов Н.М. Отчет об археологических исследованиях на р. Деркул за 1988 г. // Архив ИН КН МОН РК, ф. 2, оп. 2, д. 2234

4. Моргунова Н.Л. Отчет об археологических исследованиях на р. Деркул у с. Кузнецово Каменского района Уральской области по Открытому листу, выданному Институтом истории, археологии и этнографии им. Ч.Ч. Валиханова /от 24.06.91 г./ // Архив ИН КН МОН РК, ф. 2, оп. 1, д. 2362

5. Моргунова Н.Л. Неолит и энеолит юга лесостепи Волго-Уральского междуречья. Оренбург: Южный Урал, 1995. 224 с.

\section{Сведения об авторах:}

Мамиров Талгат Базарбаевич - кандидат исторических наук, директор, Филиал Института археологии им. А.Х. Маргулана в г. Нур-Султан (г. Нур-Султан, Казахстан); tmamirov@mail.ru

Баиров Нурсултан Малибаевич - магистр педагогического образования, младший научный сотрудник, Институт археологии им. А.Х. Маргулана (г. Алматы, Казахстан); nmbairov91@mail.ru

Клышев Ерлан Ерсаинович - магистр истории, младший научный сотрудник, Институт археологии им. А.Х. Маргулана (г. Алматы, Казахстан); Klishev_erlan82@mail.ru

Мамиров Кайрат Базарбаевич - специалист истории, Институт археологии им. А.Х. Маргулана (г. Алматы, Казахстан); kairatm_1985@mail.ru

Куандык Самрат Русланулы - магистрант археологии и этнологии очной формы обучения, Институт археологии им. А.Х. Маргулана (г. Алматы, Казахстан); s.r.kuandyk@mail.ru

\section{8 ЖЫЛҒЫ БАТЫС ҚАЗАҚСТАН ОБЛЫСЫНДАҒЫ ТАС ДӘУІРІНЕ ЖҮРГІЗІЛГЕН ДАЛАЛЫҚ ЗЕРТТЕУЛЕР} (алдын ала хабарлау)

\section{Т.Б. Мамиров, Н.М. Баиров, Е.Е. Клышев, К.Б. Мамиров, С.Р. Куандық}

Мақалада 2018 ж. Деркул өзені алабындағы тас ғасыры тұрағына Ә.Х. Марғұлан атындағы Археология институты жүргізген далалық зерттеулер туралы алдын ала мәліметтер келтіріледі. Вавилино 1 және Деркул 1 ескерткіштері Деркул өзенінің алқабында орналасқан, бүлінбеген мәдени қабатының болуы бұл ескерткіштерді аймақтың тас ғасырын зерттеу үшін бірегей болып табылады, себебі Батыс Қазақстанда мәдени қабаты сақталған ескерткіштер өте сирек. 2018 жылы жүргізілген археологиялық қазба жұмыстары ескерткіштердегі қуатты мәдени шөгінділердің бары және тас артефактілері, қыш сынықтары, сүйек қалдықтары түріндегі бай археологиялық жәдігерлердің бар екенін көрсетті. Алғашқы күндері неолит-энеолиттік дәуірінің ескерткіштеріне сәйкес мерзімделді, нақтырақ жасы радиокөміртекті талдаудың негізінде анықталады. Сүйек қалдықтарының санының көп табылуы олардың түрлік сұрыпталуының анықталуына қолайлы жағдай туғызады, сондай-ақ өңірдегі олардың кейбір түрлерінің қолға үйретілуі мәселелері де анықталуын шешуі мүмкін. Қазіргі уақытта ескерткіштер апаттық санатқа жатады, сондықтан оларды жылдамырақ зерттеу қажеттілігі туындап отыр.

Түйін сөздер: археология, тас ғасыры, неолит, энеолит, стратиграфия, сүйек қалдықтары, мәдениет, өнеркәсіп, керамика, тас шикізаты 


\section{FIELD STUDIES OF THE STONE AGE IN THE WESTERN KAZAKHSTAN REGION IN 2018 (preliminary report)}

\section{T.B. Mamirov, N.M. Bairov, E.E. Klyshev, K.B. Mamirov, S.R. Kuandyk}

This article is devoted to presents a preliminary information about the field research conducted by the A.Kh. Margulan Institute of Archaeology in the Stone Age sites in the basin of the Derkul river in 2018. Sites Vavilino 1 and Derkul 1 are located in the valley of the river Derkul, and have preserved cultural layers, which makes these monuments unique for the study of the stone age of the region, as there are only a few monuments with a preserved cultural layer in Western Kazakhstan. The archaeological excavations in 2018 showed the presence of powerful cultural deposits, rich archaeological finds: stone artifacts, fragments of ceramics, bone remains. Monuments are pre-dated to the Neolithic-Eneolithic time, radiocarbon data will give a more accurate age. The presence of a large number of bone residues will determine their species identity, and it is also possible to solve the questions of the domestication of some of them in the region. Currently, the monuments are classified as emergency, so their study is of great relevance.

Keywords: archaeology, Stone Age, Neolithic, Eneolithic, stratigraphy, bone debris, culture, industry, ceramics, stone raw materials

\section{REFERENCES}

1. Malov, N. M. 1986. In Archive A.Kh. Margulan Institute of Archaeology, fund 11, inv. 2, dossier 3046 (in Russian).

2. Malov, N. M. 1988. In Arheologicheskie otkrytija 1986 goda (Archaeological Discoveries in 1986). Moscow: "Nauka" Publ., 486 (in Russian).

3. Malov, N. M. 1989. In Archive A.Kh. Margulan Institute of Archaeology, fund. 2, inv. 2, dossier 2234 (in Russian).

4. Morgunova, N. L. 1991. In Archive A.Kh. Margulan Institute of Archaeology, fund. 2, inv. 1, dossier 2362 (in Russian).

5. Morgunova, N. L. 1995. Neolit i jeneolit juga lesostepi Volgo-Ural'skogo mezhdurech'ja (Neolithic and Eneolithic of the south of forest-steppe of the Volga-Ural interfluve). Orenburg: "Yuzhnyi Ural" Publ. (in Russian).

\section{About the Authors:}

Mamirov Talgat B. Candidate of Historical Sciences, Director, Branch of the A.Kh. Margulan Archeology Institute in Nur-Sultan (Nur-Sultan, Kazakhstan); tmamirov@mail.ru

Bairov Nursultan M. Master of Education, Junior Researcher, A.Kh. Margulan Archeology Institute (Almaty, Kazakhstan);nmbairov91@mail.ru

Klyshev Yerlan Y. Master of History, Junior Researcher, A.Kh. Margulan Archeology Institute (Almaty, Kazakhstan); Klishev_erlan82@mail.ru

Mamirov Kairat B. A history specialist, A.Kh. Margulan Archeology Institute (Almaty, Kazakhstan); kairatm_1985@mail.ru

Kuandyk Samrat R. Master student of archaeology and ethnology full-time tuition, A.Kh. Margulan Archeology Institute, Almaty, Kazakhstan; s.r.kuandyk@mail.ru

\footnotetext{
Мүдделер қақтығысы туралы ақпаратты ашу. Авторлар мүдделер қақтығысының жоқтығын мәлімдейді. / Раскрытие информации о конфликте интересов. Авторы заявляют об отсутствии конфликта интересов. / Disclosure of conflict of interest information. The authors claims no conflict of interest.

Мақала туралы ақпарат / Информация о статье / Information about the article. Редакцияға түсті / Поступила в редакцию / Entered the editorial office: 07.10.2018. Рецензенттер мақұлдаған / Одобрено рецензентами / Approved by reviewers: 15.10.2018. Жариялауға қабылданды / Принята к публикации / Accepted for publication: 23.10.2018.
} 